\title{
PERBANDINGAN RETINAL GANGLION CELL THICKNESS DAN PERIMETRI PASIEN DIABETES MELITUS TIPE 2
}

\author{
Sherly Muchlis, Ardizal Rahman, Weni Helvinda \\ ${ }^{1}$ Fakultas Kedokteran, Universitas Andalas, Bagian Ilmu Kesehatan Mata RSUP DR.M.Djamil Padang \\ email: sherlymuchlis@gmail.com \\ ${ }^{2}$ Fakultas Kedokteran, Universitas Andalas, Bagian Ilmu Kesehatan Mata RSUP DR.M.Djamil Padang \\ email: ardizalrahman@yahoo.com \\ ${ }^{3}$ Fakultas Kedokteran, Universitas Andalas, Bagian Ilmu Kesehatan Mata RSUP DR.M.Djamil Padang \\ email: helvindawenispm@gmail.com
}

Submitted : 13-04-2020, Reviewer:17-04-2020, Accepted: 17-04-2020

\begin{abstract}
Introduction: Diabetic retinopathy $(R D)$ is a microvascular complication that often occurs in diabetes mellitus (DM). Retinal ganglion cells $(R G C)$ are reduced in the early stages of DM, even before microvascular abnormalities are seen on the retina. Methods: Sample of 35 eyes of non RD RD type 2 patients and 35 mild non proliferative diabetic retinopathy (NPDR) eyes After examination of ophthalmological status, perimetry and optical coherence tomography (OCT) were examined. Results: The mean MD on non-RD type 2 DM -2.74 \pm 3.5 mild NPDR $-5.61 \pm 4.5$ with $p$ value 0.414 . The average non-RD type 2 PSD DM was $-3.35 \pm 3.3$, mild NPDR was $4.16 \pm 1.4$ with a $p$ value of 0.206 . The mean $R G C$ thickness of patients with non-RD type $2 \mathrm{DM}$ was $83.8 \pm 7.4 \mu \mathrm{m}$, mild NPDR $82.7 \pm 8.1 \mu \mathrm{m}$. There was a decrease in the value of RGC thickness, MD and PSD in patients with type 2 DM, but it was not statistically significant. Conclusion: No significant difference was found in RGC thickness in DM patients between non-RD and mild NPDR. No significant difference was found between MD and PSD in $D M$ patients between non-RD and mild NPDR. No significant relationship was found between RGC thickness and perimetry in DM patients between non-RD and mild NPDR. Keywords: Diabetic retinopathy, mild NPDR, RGC Thickness, perimetry, OCT
\end{abstract}

\section{Abstrak}

Pendahuluan : Retinopati diabetikum (RD) merupakan salah satu komplikasi mikrovaskular yang sering terjadi pada diabetes mellitus (DM). Retinal ganglion cell (RGC)yang berkurang pada stadium awal DM, bahkan sebelum terlihat kelainan mikrovaskuler pada retina. Metode: Sampel 35 mata pasien DM tipe 2 non RD dan 35 mata mild non proliferative diabetic retinopathy (NPDR) Setelah pemeriksaan status oftalmologi, dilakukan pemeriksaan perimetri dan optical coherence tomography (OCT). Hasil: Rerata MD pada DM tipe 2 non RD $-2,74 \pm 3,5$ mild NPDR $-5.61 \pm 4,5$ dengan $\mathrm{p}$ value 0,414 . Rerata PSD DM tipe 2 non RD $-3,35 \pm 3,3$, mild NPDR 4,16 $\pm 1,4$ dengan $\mathrm{p}$ value 0,206 . Rerata RGC thickness penderita DM tipe 2 non RD adalah 83,8 \pm 7,4 $\mu \mathrm{m}$,mild NPDR 82,7 $\pm 8,1 \mu \mathrm{m}$ Terdapat penurunan nilai RGC RGC thickness, MD dan PSD pada pasien DM tipe 2, namun secara statistik tidak bermakna. Kesimpulan: Tidak ditemukan perbedaan yang bermakna RGC thickness pada pasien DM antara non RD dengan mild NPDR. Tidak ditemukan perbedaan yang bermakna MD dan PSD pada pasien DM antara non RD dengan mild NPDR. Tidak ditemukan hubungan yang bermakna antara RGC thickness dan perimetri pada pasien DM antara non RD dengan mild NPDR..

Kata Kunci: Retinopati diabetikum, mild NPDR,RGCThickness,perimetri,,OCT 


\section{PENDAHULUAN}

Diabetes melitus (DM) merupakan suatu kelainan metabolik dengan karakteristik hiperglikemia kronik yang terjadi akibat kelainan sekresi insulin, kerja insulin atau keduanya. Berdasarkan patofisiologinya, DM diklasifikasikan menjadi dua jenis yaitu insulin dependent (DM tipe 1) dan non-insulin dependent (DM tipe 2). Komplikasi DM meliputi kerusakan, disfungsi dan kegagalan multipel organ dalam jangka panjang. ${ }^{1,2}$

Berdasarkan International Diabetes Federation (IDF), prevalensi DM di seluruh dunia pada tahun 2000 pada kelompok usia diatas 20 tahun diperkirakan sekitar 151 juta orang, dan meningkat menjadi 194 juta pada tahun 2003. Angka ini diperkirakan akan terus mengalami peningkatan hingga 334 juta pada tahun 2025.,4 Penelitian oleh Cavan et al (2015) yang mengevaluasi prevalensi DM di seluruh dunia menemukan bahwa diperkirakan 321 juta orang menderita DM dan lebih dari setengahnya tidak terdiagnosa. ${ }^{2}$ Namun, saat ini IDF memperkirakan sekitar 425 juta penduduk di seluruh dunia menderita DM tipe $2 .^{5}$

Prevalensi DM tertinggi adalah di India, diikuti oleh Cina, Amerika Serikat, dan Indonesia menempati peringkat ke 4. Di Indonesia, prevalensi DM mengenai sekitar 10 juta orang dan jumlah ini diperkirakan meningkat menjadi 16 juta pada tahun 2040. ${ }^{2}$ Prevalensi DM paling tinggi ditemukan pada daerah urban dibandingkan daerah ibukota provinsi. Berdasarkan profil kesehatan Provinsi Sumatra Barat tahun 2013, jumlah penduduk < 15 tahun adalah $30,95 \%$, usia 15-64 tahun adalah $63,58 \%$, dan usia > 65 tahun adalah 5,46\%. ${ }^{6}$ Berdasarkan Laporan Tahunan Dinas Kesehatan Kota Padang tahun 2018 didapatkan jumlah penderita DM adalah sebanyak 60.854 orang. Prevalensi DM tertinggi berada di wilayah kecamatan Padang Timur (5569 kasus) dan prevalensi terendah ditemukan di wilayah kecamatan Bungus (1674 orang). ${ }^{7}$

Retinopati diabetikum (RD) merupakan salah satu komplikasi mikrovaskular yang sering terjadi pada DM dan merupakan penyebab kebutaan pada kelompok usia pertengahan dan usia lanjut yang paling sering di Amerika Serikat dan beberapa negara maju lainnya. ${ }^{4}$ Penelitian metaanalisis yang mengumpulkan 35 studi prevalensi RD di seluruh dunia tahun 19802008, mendapatkan prevalensi RD pada pasien DM adalah sekitar $35,4 \% .^{8} \mathrm{Di}$ Amerika Serikat, diperkirakan sekitar 28,5$40,3 \%$ penderita DM tipe 2 memiliki komplikasi RD, dan sekitar 4,4-8,2\% mengalami Vision-Threatening Diabetic Retinopathy (VTDR). Sebaliknya, sebagian besar penderita DM tipe 2 di negara Asia memiliki prevalensi RD sekitar 12,1-23,0\%, dengan prevalensi VTDR 4,3-4,6\%. ${ }^{7}$ World Health Organization (WHO) tahun 2004 melaporkan sekitar $4,8 \%$ penduduk di seluruh dunia menjadi buta akibat RD. Secara global, RD menduduki peringkat ke empat penyebab kebutaan, setelah katarak, glaukoma, dan degenerasi makula. ${ }^{9}$

Berdasarkan hasil Riskesdas Indonesia tahun 2013, komplikasi RD terjadi pada 33,40\% kasus DM tipe 2. ${ }^{3}$ Penelitian oleh Rahman (2002) di RSUP DR M Djamil Padang mendapatkan sekitar $50,7 \%$ penderita DM mengalami RD, baik non proliferatif ataupun proliferatif. ${ }^{10}$ Soewondo et al mendapatkan NPDR sebanyak 8,3\%, sebagai komplikasi dari DM. ${ }^{3}$

Berdasarkan tingkat keparahan penyakit, RD diklasifikasikan menjadi non proliferative diabetic retinopathy (NPDR) yang dibagi menjadi mild, moderate, dan severe NPDR, dan tahap lanjut berupa proliferative diabetic retinopathy (PDR). 
Progresivitas RD biasanya terjadi secara bertahap mulai dari mild NPDR yang ditandai dengan adanya mikroaneurisma, kemudian pada stadium yang lebih berat dapat ditemukan perdarahan retina, hard exudates, neovaskularisasi, perdarahan preretina, perdarahan vitreus, ablasio retina traksional atau edema makula. ${ }^{11}$ Yang et al (2015) mengumpulkan penelitian prevalensi DM tipe 2 dengan RD di Asia dan mendapatkan prevalensi PDR sebesar 6\% dan NPDR sebesar 27\%. ${ }^{12}$ Nowak dan Grzybowski (2018) mendapatkan prevalensi RD dan mendapatkan prevalensi mild NPDR sebesar 10,4\%, moderate NPDR sebesar 9,09\%, severe NPDR sebesar 1,3\%, dan PDR sebesar $1,8 \% .{ }^{13}$ Deteksi dini RD dan kontrol teratur diketahui dapat menurunkan resiko moderate visual loss akibat edema makula hingga 50\%-60\% dan severe visual loss akibat PDR hingga 90\%. ${ }^{\text {dikutip dari } 14}$

Kondisi hiperglikemia pada DM menyebabkan kerusakan struktural pada endotel dan tight junction pembuluh darah retina sehingga terjadi kerusakan bloodretinal barrier dan peningkatan permeabilitas pembuluh darah. ${ }^{15,16}$ Meskipun RD merupakan suatu kelainan vaskular, namun pada dasarnya retina bukan merupakan struktur yang terutama terdiri dari jaringan pembuluh darah melainkan jaringan saraf dengan suplai darah. ${ }^{17}$

Hiperglikemia diperkirakan tidak hanya mempengaruhi pembuluh darah retina namun juga jaringan saraf atau neuroretina sehingga sering didapatkan kelainan fungsional retina yang terjadi lebih awal pada penderita DM tanpa adanya kelainan vaskular. ${ }^{17}$ Beberapa penelitian terdahulu telah membuktikan bahwa neurodegenerasi retina pada DM dapat terjadi lebih dulu dibandingkan perubahan vaskular. Neurodegenerasi retina pada DM terutama melibatkan apoptosis badan sel ganglion dan kerusakan pada sel glia. Atrofi sel ganglion dan degenerasi inner nuclear layer pada DM pertama kali dijelaskan oleh Wolter, bahwa degenerasi sel saraf secara bertahap terjadi lebih awal pada DM dan diperkirakan kondisi inilah yang menyebabkan terjadinya perubahan vaskular. Penelitian selanjutnya pada hewan coba yang diinduksi dengan DM setelah 12 minggu juga didapatkan penurunan jumlah serabut saraf retina. Barber et al (1988) kemudian menilai konsep ini pada hewan coba yang diinduksi dengan DM selama 7,5 bulan. Pada penelitian tersebut didapatkan apoptosis yang signifikan pada neuroretina tanpa adanya apoptosis yang signifikan pada sel endotel pembuluh darah. ${ }^{18}$ Sejalan dengan penelitian tersebut, Martin et al (2004) juga menemukan kematian sel ganglion retina melalui jalur apoptosis pada hewan coba yang diinduksi DM selama 14 minggu. ${ }^{19}$

Apoptosis merupakan respon inflamasi dan fragmentasi DNA yang disebabkan oleh aktivitas endonuklease. Apoptosis dapat dilihat melalui pemeriksaan histologi dengan ditemukannya kondensasi sitoplasma, fragmentasi dan kerusakan deoxyribonucleic acid (DNA) rantai tunggal maupun rantai ganda. ${ }^{18}$ Kadar glukosa yang tinggi dalam darah menyebabkan peningkatan metabolit eksitotoksik seperti glutamat, branch chain amino acid, dan homosistein yang merupakan metabolit yang berpotensi menyebabkan kerusakan neuron. Perubahan kadar metabolit ini mengaktivasi beberapa jalur metabolik seperti protein kinase $\mathrm{C}$, advance glycation end products, dan jalur hexosamine yang mengakibatkan peningkatan stress oksidatif dan menurunnya kadar faktor - faktor neurotropik yang pada akhirnya menyebabkan apoptosis neuron pada penderita diabetes. ${ }^{20}$

Optical coherence tomographic (OCT; Carl Zeiss, Meditec, California, USA) merupakan suatu teknologi pencitraan yang dapat mendeteksi secara kuantitatif struktur retina dengan akurat dan bisa 
menampilkan gambar retina dengan resolusi 8-10 $\mu \mathrm{m} .{ }^{21}$ Neurodegenerasi retina pada DM terutama melibatkan apoptosis sel ganglion, oleh karena itu evaluasi secara in vivo terhadap proses neurodegenerasi retina pada DM dapat dinilai melalui RGC dan RNFL thickness dengan OCT. Carpineto et al (2016) menemukan adanya penurunan yang signifikan pada lapisan retinal ganglion cells (RGC) dan retinal nerve fiber layer (RNFL) thickness pada kelompok DM tanpa RD dan kelompok mild NPDR. ${ }^{16}$ Shi et al (2017) mengevaluasi perubahan RGC dan RNFL thickness pada stadium awal RD serta faktor resiko terkait dan didapatkan bahwa penurunan RGC dan RNFL thickness pada stadium awal RD dipengaruhi oleh faktor resiko seperti durasi DM, indeks massa tubuh (IMT), kadar lipid dalam darah, dan kadar HbA1c. ${ }^{17}$ Fetriyanita (2018) mengevaluasi lapisan RGC dan RNFL pada penderita DM berdasarkan durasi menderita DM dan didapatkan penipisan lapisan RGC dan RNFL sejalan dengan durasi DM yang lebih lama. ${ }^{22}$

Kerusakan RGC pada stadium awal DM diperkirakan dapat menyebabkan defisit fungsional retina yang secara klinis penurunan sensitivitas retina. Sensitivitas retina dapat dinilai secara psychophysical dengan perimetri atau electrophysiological dengan electroretinogram (ERG). Shortwavelength automated perimetry (SWAP) merupakan salah satu teknik pemeriksaan yang efektif untuk menilai sensitivitas retina. Metode SWAP menggunakan stimulus biru dengan latar belakang kuning untuk mengevaluasi blue cone photoreceptor sehingga lebih efektif dalam menilai perubahan pada RGC di daerah makula terutama untuk deteksi dini RD. Abrishami et al (2011) menilai penurunan sensitivitas retina dengan teknik SWAP dan menemukan perbedaan sensitivitas retina yang bermakna pada pasien DM tipe 1 tanpa $\mathrm{RD}$ (Mean deviation/ MD $-6,51 \mathrm{~dB}$ ) dibandingkan dengan kelompok kontrol (MD -3,0 dB). ${ }^{14}$ Hellgren et al (2014) mengevaluasi progresivitas RD dengan perimetri dan menemukan disfungsi retina sejalan dengan lama menderita DM meskipun tidak ditemukan perubahan yang bermakna pada funduskopi. ${ }^{23}$ Adil (2018) mengevaluasi fungsi visual untuk menilai neurodegenerasi retina pada penderita DM tanpa RD di RSUP dr. M. Djamil Padang dan didapatkan hubungan yang bermakna antara DM tipe 2 dengan penurunan sensitivitas kontras monokuler dan penurunan sensitivitas lapangan pandang dengan teknik SWAP. ${ }^{24}$ Namun demikian, penelitian yang menilai perubahan RGC thickness dan sensitivitas retina pada DM tipe 2 dengan mild NPDR dan tanpa RD belum banyak dilakukan sebelumnya. Berdasarkan latar belakang ini peneliti ingin mengetahui lebih lanjut mengenai gambaran RGC thickness dan perimetri pada pasien DM tipe 2 dengan mild NPDR dan tanpa RD di RSUP dr. M. Djamil Padang.

\section{METODE PENELITIAN}

Penelitian ini merupakan studi observasional dengan dengan desain cross sectional. Populasi penelitian adalah semua pasien DM yang sudah didiagnosa DM tipe 2 oleh bagian Ilmu Penyakit Dalam RSUP. DR. M. Djamil Padang dan memenuhi kriteria inklusi penelitian. Semua sampel penelitian akan di periksa status oftalmologi, dilakukan pemeriksaan perimetri dan OCT. Pemiliha subjek berdasarkan konsekutif. Perkiraan besar sampel minimum untuk setiap kelompok ditentukan dengan rumus penelitian cross sectional, dengan total jumlah sampel 70 mata.

Penelitian dilakukan di Poliklinik Mata RSUP Dr.M. Djamil Padang yang dilaksanakan Desember 2019 sampai dengan April 2020. Alat pemeriksaan yang digunakan adalah slit lamp, funduskopi, 
tonometer non kontak, perimetry Humphrey, dan OCT. Kriteria inklusi berupa:

Kelompok mild NPDR :

1. Penderita yang sudah didiagnosa DM tipe 2 oleh dokter penyakit dalam

2. Bersedia ikut serta dalam penelitian dan menyanggupi mematuhi aturan pemeriksaan yang akan dilakukan

3. Usia antara 40-60 tahun.

4. Pada funduskopi direk ditemukan setidaknya satu mikroaneurisma dan tidak terdapat kriteria retinopati diabetikum yang lebih berat.

5. Tekanan intraokuler $<21 \mathrm{mmHg}$, dan beda rasio c/d kedua mata $\leq 0,2$ dengan batas rasio $\mathrm{c} / \mathrm{d} \leq 0,6$.

Kelompok penderita DM tanpa RD :

1. Penderita yang sudah didiagnosa DM tipe 2 oleh dokter penyakit dalam

2. Bersedia ikut serta dalam penelitian dan menyanggupi mematuhi aturan pemeriksaan yang akan dilakukan.

3. Usia antara 40-60 tahun.

4. Funduskopi normal

5. Tekanan intraokuler $<21 \mathrm{mmHg}$, dan beda rasio c/d kedua mata $\leq 0,2$ dengan batas rasio $\mathrm{c} / \mathrm{d} \leq 0,6$.

Kriteria eksklusi berupa:

1. Miopia $>-3.00 \mathrm{D}$

2. Terdapat kelainan pada segmen anterior (proses infeksi, inflamasi, dll)

3. Terdapat kekeruhan media refraksi (katarak matur, kekeruhan vitreus)

4. Riwayat glaukoma dan kelainan saraf optik lain.

Definisi Operasional:

1. Pasien DM tipe 2

- Definisi : Penderita DM tipe 2 dibagian penyakit dalam dan pada pemeriksaan segmen posterior dengan funduskopi direk dengan pupil dilatasi ditemukan dengan atau tanpa mikroaneurisma, namun tidak ditemukan kriteria retinopati diabetikum yang lebih berat.

- Cara Ukur : Funduskopi dengan pupil dilatasi

- Alat Ukur : Oftalmoskopi direk

- Hasil Ukur :

- Tanpa mikroaneurisma (tanpa RD)

- Mikroaneurisma (mild NPDR)

- Skala Ukur : kategorik

2. RGC thickness

- Defenisi : Rata-rata ketebalan RGC di daerah makula

- Cara ukur : Mengukur rata-rata RGC thickness di daerah makula seluas $6 \times 6 \mathrm{~mm}^{2}$

- Alat ukur : OCT (macular cube $512 \times 128)$

- Hasil ukur : Rerata RGC thickness dalam satuan $\mu \mathrm{m}$

- Skala ukur : Numerik.

3. Perimetri

- Definisi : Fungsi visual retina terutama pada area makula yang berkaitan dengan sel ganglion retina.

Cara Ukur : Menilai mean deviation (MD) dan Pattern Standard Deviation (PSD) dengan teknik SWAP.

- Alat Ukur : Perimetri Humphrey

- Hasil Ukur : desibel (dB) dan persen (\%)

- Skala Ukur : numerik

Sampel dibagi menjadi 2 kelompok yaitu kelompok mild NPDR dan kelompok DM tanpa RD. Informed consent pasien. Sebelum dilakukan pemeriksaan terhadap sampel yang memenuhi kriteria. Setelah mendapat persetujuan, maka data-data pasien dan hasil pemeriksaan yang sudah 
dilakukan, dicatat dalam status khusus penelitian.

Dilakukan pemeriksaan tajam penglihatan secara monokular, mata diperiksa pada jarak 6 meter dari papan Snellen. Tajam penglihatan diperiksa tanpa koreksi atau dengan koreksi dengan menggunakan autorefractometry. Dilakukan pemeriksaan TIO dengan tonometri non kontak dan bila didapatkan TIO $\leq 21$ $\mathrm{mmHg}$, mata pasien ditetes Tropicamide $1 \%$ dan dilakukan pemeriksaan segmen posterior menggunakan oftalmoskop direk, jika terdapat kelainan maka subyek dieksklusi.

Pada kelompok mild NPDR, mata yang dimasukkan ke dalam penelitian adalah satu mata dengan mild NPDR dimana terdapat mikroaneurisma pada pemeriksaan oftalmoskop direk atau apabila ditemukan pada kedua mata maka diambil satu mata dengan visus terbaik atau mata kanan apabila visus kedua mata sama. Pada kelompok DM tanpa RD, mata yang dimasukkan ke penelitian adalah mata dengan visus terbaik. Jika visus kedua mata sama, maka yang dimasukkan ke dalam penelitian adalah mata kanan.

Pada kedua kelompok sampel selanjutnya dilakukan pemeriksaan OCT pada mata yang terpilih untuk menilai RGC thickness dengan protokol Macular cube 512x128. Pemeriksaan dilakukan di ruangan nyaman dan tenang di Poliklinik Mata RSUP Dr. M. Djamil Padang :

Pada kedua kelompok sampel dilakukan pemeriksaan perimetri Humphrey pada mata yang terpilih dengan teknik SWAP, tes patern: sentral 24-2, strategi: SITA standar. Hasil pemeriksaan perimetri dinilai dengan MD, PSD dan uji reliabilitas (false positive, false negative, dan fixation loss). Hasil dianggap terpercaya jika false positive $\square$ $20 \%$, false negative $\square 33 \%$, dan fixation loss $\square 20 \%$. Jika lebih parameter reliabilitas tersebut maka dianggap tidak memenuhi syarat dan dilakukan pemeriksaan ulang.

\section{HASIL}

Penelitian ini dilakukan selama bulan Desember 2019 - Maret 2020, berupa pemeriksaan perimetri dan OCT pada 70 mata pasien DM tipe 2 yang mengalami non RD dan mild NPDR. Subyek pada penelitian ini adalah pasien yang sudah di diagnosa oleh bagian penyakit dalam dengan DM tipe 2 dan memenuhi kriteria inklusi dan ekslusi. Batas usia sampel dari 40 tahun hingga 60 tahun Ttabel 1)

Tabel 1. Distribusi subjek penelitian berdasarkan usia dan jenis kelamin

\begin{tabular}{llll}
\hline \multirow{2}{*}{ Karakteristik } & \multicolumn{2}{l}{ DM tipe 2 } & \\
\cline { 2 - 3 } & $\begin{array}{l}\text { Mild } \\
\text { NPDR }(\%)\end{array}$ & $\begin{array}{l}\text { Tanpa } \\
\text { RD }(\%)\end{array}$ & \\
\hline Usia & & & \\
$40-45$ & $2(2,8)$ & $11(15,5)$ & 13 \\
$46-50$ & $12(16,9)$ & $9(12,7)$ & 21 \\
$51-55$ & $14(19,7)$ & $8(11,3)$ & 22 \\
$56-60$ & $7(9,9)$ & $7(9,9)$ & 14 \\
Jumlah & $35(49,3)$ & $35(49,3)$ & 70 \\
Jenis & & & \\
Kelamin & & & \\
Laki-laki & $15(21,1)$ & $17(2,9)$ & 32 \\
Perempuan & $20(28,2)$ & $18(25,4)$ & 38 \\
Jumlah & 35 & 35 & 70 \\
\hline
\end{tabular}

Tabel 1 menjelaskan distribusi frekuensi penderita DM tipe 2 berdasarkan usia dan jenis kelamin. Usia terbanyak pada mild NPDR adalah pada kelompok usia 5155 tahun $(19,7 \%)$. Usia terbanyak pada non DR adalah pada kelompok usia 40-45 tahun $(15,5 \%)$. Jenis kelamin terbanyak pada kelompok mild NPDR adalah perempuan sebanyak 20 mata $(28,2 \%)$, sedangkan jenis kelamin terbanyak pada pasien non DR adalah perempuan sebanyak 18 mata $(25,4 \%)$. 
Penilaian RGC thickness di dapat berdasarkan gambaran cross sectional dari area makula menggunakan pemeriksaan Cirrus OCT macular cube $(512 \times 128)$. Algoritme analisis RGC bisa mendeteksi dan mengukur ketebalan RGC di makula pada area $6 \times 6 \mathrm{~mm}^{2}$ di pusat fovea. ${ }^{21,52}$ Nilai ketebalan yang didapat adalah ketebalan rata-rata, mean minimum thickness (ketebalan dari sektor yang paling tipis) kemudian di bandingkan rerata RGC thickness pasien DM tipe 2 antara non DR dengan mild NPDR menggunakan uji korelasi Pearson (Tabel 2)

Tabel 2. Perbandingan RGC thickness pada pasien DM tipe 2 antara non diabetik retinopati dengan mild NPDR

\begin{tabular}{lll}
\hline Kelompok & $\begin{array}{l}\text { Rerata } \\
\text { RGC } \\
\text { thickness }\end{array}$ & P value \\
\hline Mild NPDR & $82,7 \pm 8,1$ & 0,316 \\
DM tanpa & $83,8 \pm 7,4$ & \\
RD &
\end{tabular}

*uji korelasi Pearson

Pada penelitian ini di gunakan uji korelasi Pearson, didapatkan bahwa tidak ada perbedaan yang bermakna RGC thickness pada pasien DM tipe 2 antara non DR dengan mild NPDR dengan nilai $\mathrm{P}$ value 0,316 .

Mean deviation adalah hasil pengukuran rata-rata sensitivitas retina, yang merupakan perbedaan antara nilai threshold titik di retina pada pasien dengan nilai threshold populasi normal yang umurnya sesuai. MD didapat dari total plot penyimpangan dan menandakan depresi penglihatan pasien dalam satuan desibel (dB). Angka positif menunjukkan bahwa sensitivitas rata-rata di atas normal untuk usia tersebut dan angka negatif menunjukkan sensitivitas rata-rata di bawah normal untuk usia tersebut (Tabel 3). ${ }^{63}$
Tabel 3 Perbandingan nilai Mean Deviation pada pasien DM tipe 2 antara non diabetik retinopati dengan mild NPDR

\begin{tabular}{lcc}
\hline \multicolumn{1}{c}{ Kelompok } & $\begin{array}{c}\text { Rerata } \\
\text { MD }(\mathrm{db})\end{array}$ & P value \\
\hline Mild NPDR & $-5.61 \pm 4,5$ & 0,414 \\
DM tanpa & $-2,74 \pm 3,5$ & \\
RD &
\end{tabular}

*Uji korelasi Pearson

Untuk menilai perbandingan nilai Mean Deviation pada penelitian ini di gunakan uji korelasi Pearson, didapatkan bahwa tidak ada perbedaan yang bermakna nilai Mean Deviation pada pasien DM tipe 2 antara non $\mathrm{RD}$ dengan mild NPDR dengan nilai $\mathrm{P}$ value 0,414 .

$\begin{array}{ccc}\text { Pattern } & \text { standard deviation } \\ \text { menunjukkan } & \text { seberapa } & \text { perbedaan }\end{array}$ sensitivitas retina dari satu sama lain. PSD berasal dari plot total penyimpangan. PSD akan rendah nilainya pada lapangan pandang yang normal, penurunan lapangan pandang yang merata, dan pada lapangan pandang yang buta sama sekali. Nilai PSD akan tinggi pada penurunan lapangan pandang terlokalisir moderate hingga berat. PSD dikatakan abnormal jika nilai yang ditemukan berada $<5$ persen dari populasi normal $(\mathrm{P}<5 \%) .{ }^{64,65}$ Pada penelitian ini perbandingan PSD pasien DM tipe 2 antara non DR dengan mild NPDR dinilai menggunakan uji korelasi Pearson (tabel 4).

Tabel 4. Perbandingan nilai PSD pada pasien DM tipe 2 antara non diabetik retinopati dengan mild NPDR

\begin{tabular}{lcc}
\hline \multicolumn{1}{c}{ Kelompok } & $\begin{array}{c}\text { Rerata } \\
\text { PSD }(\%)\end{array}$ & P value \\
\hline $\begin{array}{l}\text { Mild NPDR } \\
\text { DM tanpa }\end{array}$ & $4,16 \pm 1,4$ & 0,206 \\
RD & $3,35 \pm 3,3$ & \\
\hline
\end{tabular}

*Uji korelasi Pearson 
Tabel 5. Hubungan antara RGC thickness dan perimetri (MD dan PSD) pada pasien DM tipe 2 antara non diabetik retinopati dengan mild NPDR

\begin{tabular}{ccccccc} 
& \multicolumn{3}{c}{ Non RD } & \multicolumn{3}{c}{ Mild NPDR } \\
\cline { 2 - 7 } Pearson corelation & RGC & MD & PSD & RGC & MD & PSD \\
\hline RGC non RD & 1 &,- 092 &, 039 &,- 174 &, 130 &,- 154 \\
Sig. (2-tailed) & &, 601 &, 826 &, 316 &, 457 &, 378 \\
\hline MD non RD &,- 092 & 1 &,- 055 &,- 017 &,- 143 &, 171 \\
Sig. (2-tailed) &, 601 & &, 752 &, 922 &, 414 &, 327 \\
\hline PSD non RD &, 039 &,- 055 & 1 &, 033 &, 292 &,- 219 \\
Sig. (2-tailed) &, 826 &, 752 & &, 850 &, 089 &, 206 \\
\hline RGC Mild NPDR &,- 174 &,- 017 &, 033 & 1 &, 319 &,- 058 \\
Sig. (2-tailed) &, 316 &, 922 &, 850 & &, 062 &, 740 \\
\hline MD Mild NPDR &, 130 &,- 143 &, 292 &, 319 & 1 &,$- 488^{* *}$ \\
Sig. (2-tailed) &, 457 &, 414 &, 089 &, 062 & &, 003 \\
\hline PSD Mild NPDR &,- 154 &, 171 &,- 219 &,- 058 &,$- 488^{*}$ & 1 \\
Sig. (2-tailed) &, 378 &, 327 &, 206 &, 740 &, 003 & \\
\hline & $* * *$ Pearson test Correlation is significant at the 0.01 level (2-tailed).
\end{tabular}

Perbandingan nilai PSD pada penelitian ini menggunakan uji korelasi Pearson, didapatkan bahwa tidak ada perbedaan yang bermakna nilai PSD pada pasien DM tipe 2 antara non DR dengan mild NPDR dengan nilai $\mathrm{P}$ value 0,206 .

Pemeriksaan perimetri dapat mendeteksi gangguan sistem visual yang disebabkan oleh kerusakan sel ganglion dengan menggunakan perimetri dengan jenis pemeriksaan Short-wavelength automated perimetry (SWAP). SWAP merupakan teknik yang dikembangkan untuk menilai jalur biru-kuning atau blue on yellow (Short Wavelength Sensitive). ${ }^{59,60}$ Untuk menilai hubungan antara RGC thickness dan perimetri pada pasien DM tipe 2 antara non DR dengan mild NPDR dinilai dengan menggunakan uji korelasi Pearson (Tabel 5).

Pada penelitian ini di dapatkan bahwa tidak di dapatkan hubungan yang bermakna antara nilai RGC thickness mild NPDR ter- hadap nilai MD dan PSD pada pasien DM tipe 2 baik antara non DR dengan mild NPDR.

\section{PEMBAHASAN}

Pada penelitian ini didapatkan subjek penelitian terbanyak berjenis kelamin perempuan, hal ini sesuai dengan data epidemiologi penelitian oleh Wild (2004) dimana pada negara berkembang, didapatkan lebih banyak penderita DM perempuan dibandingkan laki-laki. Usia sampel penelitian berkisar dari 40 tahun hingga 60 tahun dengan dominasi kelompok usia 46 tahun hingga 55 tahun. ${ }^{64}$

Subjek penelitian adalah pasien yang sudah didiagnosa DM tipe 2 oleh bagian ilmu penyakit dalam, kemudian setelah dilakukan pemeriksaan funduskopi dikelompokkan menjadi non RD dan mild NPDR. Usia terbanyak pada mild NPDR adalah pada kelompok usia 51-55 tahun $(19,7 \%)$. Usia terbanyak pada non DR adalah pada kelompok usia 40-45 tahun 
$(15,5 \%)$. Jenis kelamin terbanyak pada kelompok mild NPDR adalah perempuan sebanyak 20 mata $(28,2 \%)$, sedangkan jenis kelamin terbanyak pada pasien non DR adalah perempuan sebanyak 18 mata $(25,4 \%)$.

Neurodegenerasi retina pada DM dapat terjadi lebih dulu dibandingkan perubahan vaskular menurut penelitianpenelitian terdahulu. Neurodegenerasi retina pada DM terutama melibatkan apoptosis badan sel ganglion dan kerusakan pada sel glia akibat kondisi hiperglikemia kronis. ${ }^{17,37,38}$ Penelitian terdahulu oleh Barber et al (1988) menggunakan Terminal dUTP Nick-End Labeling (TUNEL) menunjukkan terdapatnya jumlah apoptosis neuroretina yang tinggi tanpa adanya apoptosis yang signifikan pada sel endotel mencit yang diinduksi dengan streptozotocin. Neurodegenerasi retina pada DM terjadi secara bertahap dan diperkirakan sebagai penyebab terjadinya perubahan vaskular. Sel ganglion retina (RGC) secara teori dikatakan merupakan sel yang paling awal mengalami kerusakan dan apoptosis akbat proses hiperglikemia kronis. ${ }^{18}$

OCT dapat digunakan untuk menilai perubahan struktural sel ganglion retina dengan menilai ketebalan dari lapisan tersebut. Hasil pemeriksaan OCT pada ganglion cell analysis akan menunjukkan nilai rata-rata ketebalan sel ganglion retina dan nilai 6 kuadran lapisan sel ganglion retina yaitu kuadran superior, superonasal, inferonasal, inferior, inferotemporal dan superotemporal. Penelitian ini hanya mengambil nilai rata-rata ketebalan sel ganglion retina melalui gambaran cross sectional dari area makula menggunakan pemeriksaan Cirrus OCT macular cube (512x128). ${ }^{21,52}$

Dari hasil penelitian ini didapatkan rerata ketebalan sel ganglion retina pada penderita DM tipe 2 pada kelompok tanpa $\mathrm{RD}$ adalah $83,8 \pm 7,4 \mu \mathrm{m}$ sedangkan pada kelompok mild NPDR yaitu $82,7 \pm 8,1 \mu \mathrm{m}$. Nilai ini lebih tinggi bila dibandingkan dengan nilai normal rerata ketebalan sel ganglion retina yaitu $82.1 \mu \mathrm{m}$. Namun jika dibandingkan ketebalan sel ganglion retina pada penderita DM tipe 2 kelompok mild NPDR lebih tipis jika dibandingkan pada kelompok tanpa RD. Hasil ini secara analisa korelasi Pearson menunjukkan bahwa tidak terdapat hubungan yang bermakna antara ketebalan sel ganglion retina pada penderita DM tipe 2 pada kelompok tanpa RD dibandingkan dengan kelompok mild NPDR ( $\mathrm{p}$ value $>0,01$ )

Hasil penelitian ini sama dengan hasil penelitian sebelumnya. Karti (2017) melakukan penelitian ketebalan sel ganglion retina yang dinilai dengan OCT terhadap 30 orang penderita DM tanpa ditemukannya retinopati diabetika dibandingkan dengan kelompok kontrol. Mereka melaporkan adanya penurunan ketebalan rerata lapisan sel ganglion retina $(\mathrm{p}<0.05)$ dibandingkan dengan kelompok kontrol. ${ }^{65}$

Tabakci (2017) melakukan pemeriksaan terhadap 60 orang pasien DM dan 60 orang sehat sebagai kontrol dengan menilai rerata ketebalan sel ganglion retina, ketebalan sel ganglion retina kuadran superior, superotemporal, temporal, inferotemporal, inferior, inferonasal, nasal, dan superonasal. Mereka menemukan rerata ketebalan sel ganglion retina dan ketebalan sel ganglion retina di 6 kuadran menurun secara signifikan $(\mathrm{p}<0,05)$ dibandingkan kelompok kontrol. ${ }^{66}$

Penurunan ketebalan lapisan sel ganglion retina pada penderita DM tipe 2 yang dalam penelitian Karti (2017) dan Tabakci (2017) tanpa ditemukannya retinopati diabetika diduga akibat hiperglikemia kronis menyebabkan terjadinya stres oksidatif dan apoptosis yang menimbulkan kerusakan fungsi retina, kematian sel ganglion dan sel glia yang 
berdampak pada kematian sel ganglion retina.

Penelitian ini hanya mengambil nilai rerata (average) sel ganglion retina secara cross sectional. Hasil pemeriksaan average ganglion cells layer + inner plexiform layer pada penelitian ini tidak ditemukan penurunan yang signifikan dibandingkan nilai normal, baik pada penderita DM tipe 2 tanpa RD dan mild NPDR. Secara teori, penurunan ketebalan sel ganglion retina disebabkan oleh proses apoptosis sel ganglion retina yang dimulai segera setelah onset diabetes dimana hiperglikemia menyebabkan munculnya gangguan metabolik. Berbagai abnormalitas metabolik dan biokimia pada retina termasuk peningkatan kadar glutamat, akumulasi AGEP, dan peningkatan stres oksidatif telah dilaporkan menginduksi ekspresi molekul pro-apoptosis dan menyebabkan apoptosis sel neuron pada pasien DM. ${ }^{65,66}$

Penelitian oleh AM Abu El Asrar et al melaporkan stres oksidatif yang diinduksi oleh hiperglikemia menghasilkan aktivasi caspase-3 dan apoptosis pada sel ganglion retina. Peningkatan apoptosis sel ganglion retina pada mencit yang diinduksi diabetes dengan ditemukannya $10 \%$ penurunan sel ganglion retina dibanding kelompok kontrol. Penelitian eksperimental melaporkan lapisan sensori retina pada pasien diabetes tanpa retinopati diabetes menunjukkan imunoreaktivitas terhadap apoptosispromoting factors pada sel ganglion. Penelitian ini tidak dapat membuktikan sel ganglion pada pasien DM mengekspresikan faktor proapoptosis, sehingga mengakibatkan terjadinya apoptosis. ${ }^{67}$

Penelitian histologis post-mortem dari delapan mata manusia dengan diabetes teridentifikasi beberapa karakteristik perubahan patologi vaskular dan degenerasi neuron termasuk sel yang membengkak dan hialinisasi, yang dikelilingi oleh badan acidophilic yang diduga terlibat dalam proses degenerasi. Dominasi proses degeneratif ini ditemukan pada lapisan sel ganglion retina dan diikuti dengan hilangnya RNFL. Dikutip dari kepustakaan 68

Hasil penelitian ini sedikit berbeda dengan penelitian-penelitian sebelumnya. Pemeriksaan yang dilakukan pada penelitian ini dilakukan hanya sekali (cross sectional), sehingga penurunan ketebalan RGC tidak bisa dibuktikan pada penelitian ini. Nilai ketebalan rerata RGC penderita DM tipe 2 pada penelitian ini juga memperlihatkan mungkin saja ketebalan RGC ras asia lebih tebal dibandingkan ketebalan rerata RGC yang telah diteliti oleh Mwanza et al, dan mungkin saja pada hasil penelitian ini dapat terjadi penurunan ketebalan RGC pada penderita $\mathrm{DM}$ tipe 2 non $\mathrm{RD}$ dan mild NPDR jika dibandingkan kelompok kontrol.

Ketebalan RGC pasien DM tipe 2 kelompok non RD dan mild NPDR pada penelitian ini dihubungkan dengan pemeriksaan lapang pandang menggunakan perimetri Humphrey dengan teknik Shortwavelength automated perimetry (SWAP) dengan stimulus biru latar belakang kuning atau blue on yellow (Short Wavelength Sensitive) yang dapat mendeteksi gangguan sistem visual yang disebabkan kerusakan sel ganglion. ${ }^{59,60}$ Analisa hasil perimetri yang digunakan untuk menilai RGC terhadap lapang pandang adalah Mean Deviation (MD) dan Pattern Standard Deviation (PSD). MD dan PSD merupakan pengukuran rata-rata sensitivitas retina, yang merupakan perbedaan antara nilai threshold titik di retina pada pasien dengan nilai threshold populasi normal yang umurnya sesuai. Nilai MD normal jika $\geq-2 \mathrm{~dB}$, sedangkan untuk PSD semakin kecil nilainya makin bagus nilai lapang pandangnya. ${ }^{61,62}$

Pada pemeriksaan dengan perimetri Humprey untuk menilai gangguan lapangan pandang, penilaian rerata MD pada DM tipe 2 non $\mathrm{RD}-2,74 \pm 3,5$ sedangkan rerata $\mathrm{MD}$ 
pada DM tipe 2 mild NPDR $-5.61 \pm 4,5$ dengan $p$ value 0,414 . Rerata nilai PSD pada DM tipe 2 non RD -3,35 $\pm 3,3$ sedangkan rerata PSD pada DM tipe 2 mild NPDR 4,16 $\pm 1,4$ dengan $p$ value 0,206. Secara umum, nilai PSD berbanding lurus dengan penurunan nilai MD pada tiap responden meskipun tidak signifikan secara statistik. Hasil ini secara analisa korelasi Pearson menunjukkan bahwa tidak terdapat hubungan yang bermakna antara ketebalan RGC dengan nilai MD dan PSD pada penderita DM tipe 2 pada kelompok tanpa RD dibandingkan dengan kelompok mild NPDR ( $p$ value $>0,01$ ).

Hasil lapangan pandang ini didapat dengan menggunakan metode SWAP, untuk mengevaluasi blue cone photoreceptor sehingga lebih efektif dalam menilai perubahan pada RGC di daerah makula terutama untuk deteksi dini RD, karena lebih sensitif dalam mendeteksi kerusakan neuron retina dibandingkan metode konvensional (SAP).

Penurunan nilai rerata MD dan PSD pada ini juga sejalan dengan penurunan nilai RGC yang sama - sama menunjukkan penurunan yang tidak signifikan secara statistik. Pada penelitian ini dapat disimpulkan bahwa gangguan sistem visual yang disebabkan apoptosis atau kerusakan sel ganglion yang diterjemahkan dalam bentuk analisa hasil MD dan PSD perimetri mungkin saja sudah terjadi namun dalam jumlah yang sedikit, sehingga gambaran defek lapang pandang pun tidak menunjukkan gambaran yang signifikan.

Teknik blue yellow perimetri (SWAP) menggunakan latar belakang kuning dengan pencahayaan tinggi untuk mengadaptasi jalur hijau, merah dan menekan aktifitas sel rod. Kombinasi panjang gelombang dan pencahayaan khusus dari stimulus dan latar belakang ini akan mengisolasi jalur short wavelength secara optimal. Pada pemeriksaan tampak adanya penurunan sensitivitas dalam jalur $\mathrm{S}$ cone dengan tingkat kerusakan yang berbeda pada setiap lapangan pandang. Perubahan sensitivitas lapangan pandang terlihat yang menggambarkan kerusakan ganglion retina, tanpa adanya retinopati diabetik secara klinis. ${ }^{61,62}$

Sesuai dengan penelitian oleh Zico OA dkk (2014) yang melakukan perimetri pasien DM menggunakan shortwave length automated perimetry (SWAP) dan standard automated perimetry (SAP). Dilakukan pemeriksaan terhadap kelompok diabetes mellitus dan kelompok kontrol. Pada hasil didapatkan perbedaan yang signifikan antara MD dengan nilai $(-4.44 \pm 2.02 \mathrm{~dB})$ pada perimetri SWAP dan MD dengan nilai $(-0.96 \pm 1.81 \mathrm{~dB})$ pada perimetri SAP pada pasien dengan diabetes mellitus. Penelitian ini menyimpulkan perimetri dengan metode SWAP memiliki sensitivitas lebih baik dibandingkan SAP. ${ }^{69}$

Subjek penelitian ini merupakan pasien DM tipe 2 yang belum memiliki gambaran retinopati diabetik dan pasien DM tipe 2 dengan gejala retinopati diabetik awal yaitu mikroaneurisma. Walaupun dengan jenis retinopati diabetik yang awal, namun jika kontrol glikemik yang tidak baik maka kerusakan neuron juga dapat terjadi lebih cepat. Peneliti juga tidak menemukan perbedaan penurunan sensitivitas lapangan pandang yang signifikan pada ke dua kelompok responden yang berbeda usia. Sehingga durasi menderita DM dan kontrol glikemik merupakan faktor penting dalam progresifitas proses neurodegenerasi retina.

Dari 35 subjek penelitian DM tipe 2 kelompok non RD dan 35 subjek kelompok mild NPDR, 4 subjek menunjukkan gambaran penipisan $\mathrm{RGC}$ dan penurunan nilai MD yang cukup signifikan. Pada kelompok non $\mathrm{RD}$, hasil pemeriksaan mata kiri subjek no 24 memperlihatkan hasil ketebalan RGC 71, dengan MD -7,85 dB dan PSD 2,57 dan riwayat menderita DM 
tipe 2 selama 2 tahun. Anamnesa pada pasien ini didapatkan bahwa DM baru diketahui selama 2 tahun ini, tetapi dengan gula darah yang tidak terkontrol, dan pasien hanya minum obat teratur sejak 6 bulan ini.

Pada subjek kelompok mild NPDR, subjek no 5 usia 47 tahun dengan mild NPDR kedua mata, pemeriksaan pada mata dengan visus terbaik yaitu kanan ditemukan ketebalan RGC 69 dengan MD -9,05dB dan PSD 4,91, dengan riwayat diketahui DM sudah 4 tahun. Pada subjek no 22 usia 42 tahun, nilai RGC mata kanan adalah $72 \mu \mathrm{m}$ dengan MD -12,44 dB dan PSD 3,33. Mata kiri juga mengalami mild NPDR dengan visus yang lebih buruk dari mata kanan. Subjek sudah menderita DM selama \pm 7 tahun. Pada kedua subjek ini juga diketahui bahwa gula darah tidak terkontrol, dan pasien rutin minum obat DM sejak \pm 1 tahun ini. Pada subjek no 30, mata kanan subjek menunjukkan hasil rerata ketebalan RGC yang tipis sebesar $49 \mu \mathrm{m}$ dengan nilai MD 7,74 dB dan PSD $+3,35$, dan mata kiri menderita moderate NPDR. Subjek ini berusia 59 tahun dengan diketahui telah menderita DM terkontrol selama 15 tahun. Pada pasien ini, meskipun sudah menderita DM lebih lama yaitu 15 tahun, akan tetapi terkontrol obat. Pada ke empat subjek ini dapat dikatakan proses apoptosis atau kerusakan sel ganglion yang terjadi dapat sama ataupun berbeda antara ke dua mata, dan respon setiap mata terhadap kondisi hiperglikemia dipengaruhi oleh berbagai macam faktor, seperti kadar glutamat, stress oksidatif, penurunan growth factor, dan neuroinflamasi.

Hellgren KJ dkk (2014) meneliti tanda-tanda disfungsi retina pada subjek dengan DM sebelum atau di awal retinopati diabetik. Pasien tanpa retinopati, mild, atau moderat, direkrut secara berurutan dan dilakukan pemeriksaan perimetri, pengukuran visus, dan fotofundus. Perbaikan / kerusakan lapangan pandang pada subjek DM dievaluasi. Tujuh puluh empat subjek menyelesaikan observasi selama 3 tahun, dan $22 \%$ menunjukkan perburukan lapangan pandang, nilai MD global mengalami penurunan sebanyak $0.19 \mathrm{~dB}$ hingga $-1.26 \mathrm{~dB}$. Kerusakan gangguan lapangan pandang dianalisa, dan didapatkan perkembangan disfungsi retina dari waktu ke waktu, yang mewakili tandatanda awal dari neurodegenerasi retina. ${ }^{70}$

Tidak terlihat gambaran defek lapangan pandang yang signifikan pada pemeriksaan dalam penelitian ini, namun berdasarkan MD dan PSD ditemukan penurunan sensitivitas lapangan pandang. Hal ini sejalan dengan hasil penelitian yang dilakukan oleh Henricsson dan Heijl (1994) yang menyelidiki berbagai tahap retinopati diabetik menggunakan perimetri Humphrey. Pada mata tanpa retinopati diabetik nilai deviasi rata-rata melebihi $\mathrm{p}<5 \%$. Pada mata retinopati moderate dan severe, terdapat bukti yang jelas dari defek lapangan pandang, dengan penurunan nilai rata-rata penyimpangan yang signifikan pada $44 \%$ dari mata. Pada mata tanpa retinopati tidak tampak defek lapangan pandang, dan baru jelas terlihat pada derajat yang lebih berat, namun sensitivitas lapangan pandang berkurang secara signifikan. ${ }^{71}$

Berdasarkan penelitian ini dan dari beberapa penelitian lain, ternyata pemeriksaan lapangan pandang sentral pada penderita DM tipe 2 mempunyai arti yang besar secara klinis, karena perubahan dalam bidang visual merupakan indikasi kondisi patologis. Hal ini mencerminkan kelainan struktural pada mekanisme penglihatan okular dan saraf. Perubahan mikrovaskular dan neurodegenerasi retina pada penelitian dengan tikus diabetes telah menperlihatkan bahwa DM menyebabkan penurunan yang signifikan dari ketebalan lapisan plexiform bagian dalam, lapisan inti dalam, dan retina secara keseluruhan dibandingkan dengan kontrol yang sesuai usia. Gambaran 
histologis juga mengungkapkan adanya tanda tanda apoptosis di sel-sel saraf retina, terutama di lapisan sel ganglion retina. Ini menunjukkan bahwa DM meningkatkan laju apoptosis dari beberapa jenis sel di retina, termasuk neuron. ${ }^{72,73}$

Kelemahan penelitian ini antara lain, peneliti tidak dapat mengetahui secara tepat durasi responden menderita DM, serta tidak ada pertimbangan kontrol glikemik, sehingga tidak terlihat dengan jelas gambaran kontrol gula darah dari pasien yang menderita DM. Penelitian ini juga tidak membahas tentang faktor faktor diluar medikamentosa yang dapat mempengaruhi gula darah, baik dari segi berat badan, makanan, olah raga dan gaya hidup.

\section{SIMPULAN}

Berdasarkan pemeriksaan OCT, tidak ditemukan perbedaan yang bermakna RGC thickness pada pasien DM antara non RD dengan mild NPDR. Pada pemeriksaan perimetri, tidak ditemukan perbedaan yang bermakna MD dan PSD pada pasien DM antara non RD dengan mild NPDR. Tidak ditemukan hubungan yang bermakna antar RGC thickness dan perimetri pada pasien DM antara non RD dengan mild NPDR.

\section{UCAPAN TERIMAKASIH}

Terimakasih kepada seluruh pasien yang menjadi subjek penelitian ini, Fakultas Kedokteran Universitas Andalas, dan Bagian Ilmu Kesehatan Mata Fakultas Kedokteran Universitas Andalas/ RSUP DR.M.Djamil Padang.

\section{REFERENSI}

1. Deshmukh C, Jain A. Diabetes Mellitus: A Review. Int J Pure Appl Biosci. 2105;3(3):224-30.

2. Ogurtsova K, da Rocha Fernandes JD, Huang Y, Linnenkamp U, Guariguata L,
Cho NH, et al. IDF Diabetes Atlas: Global estimates for the prevalence of diabetes for 2015 and 2040. Diabetes Res Clin Pract. 2017 Jun;128:40-50.

3. Soewondo P, Soegondo S, Suastika K, Pranoto A, Soeatmadji DW, Tjokroprawiro A. The DiabCare Asia 2008 Study-Outcomes on Control and Complication of Type 2 Diabetic Patients in Indonesia. Medical Journal of Indonesia. 2010; 4 (19):235-244. Med J Indones. 2010;19(4):235-44.

4. Riskesdas. Basic Health Research of West Sumatera Province, Indonesian Ministry of Health, Health Research and Development Body. Sumatra Barat; 2008.

5. Federation ID. World Diabetes Day 2018-19. 2019.

6. Profil Kesehatan Provinsi Sumatra Barat Tahun 2013. Dinas Kesehatan Provinsi Sumatra Barat. 2013.

7. Laporan Tahunan Dinas Kesehatan Kota Padang. Dinas Kesahatan Kota Padang. 2018;

8. Yau JWY, Rogers SL, Kawasaki R, Lamoureux EL, Kowalski JW, Bek T, et al. Global prevalence and major risk factors of diabetic retinopathy. Diabetes Care. 2012 Mar;35(3):556-64.

9. Suyono. Diabetes Melitus di Indonesia. In: Buku Ajar Ilmu Penyakit Dalam. Balai Penerbit FK UI; 2006.

10. Rahman K. Epidemiologi retinopati diabetikum di bagian ilmu penyakit mata fakultas kedokteran universitas andalas/ RSUP. dr. M djamil Padang. Maj Kedokt Andalas. 2002;26:49-58.

11. Skuta GL, Cantor LB, Cioffi GA. Retinal vascular disease: Diabetic 
retinopathy. In: Retina and VItreous. San Fransisco: American Academy of Ophthalmology; 2015. p. 89-111.

12. Yang Q, Zhang Y, Zhang X, Li X. Prevalence of diabetic retinopathy, proliferative diabetic retinopathy and non-proliferative diabetic retinopathy in Asian T2DM patients: a systematic review and Meta-analysis. Int $J$ Ophthalmol. 2019;

13. Nowak BMS, Grzybowski A. Review of the epidemiology of diabetic retinopathy | Modern Retina. 2018;(July 2009).

14. Abrishami M, Daneshvar R, Yaghubi Z. Short-wavelength automated perimetry in type $\mathrm{i}$ diabetic patients without retinal involvement: A test modification to decrease test duration. Eur $J$ Ophthalmol. 2012;22(2):203-9.

15. Dimitrova N, Zamudio JR, Jong RM, Soukup D, Resnick R, Sarma K, et al. Selective Loss of Inner Retinal Layer Thickness in Type 1 Diabetic Patients with Minimal Diabetic Retinopathy. PLoS One. 2017;32(7):736-40.

16. Carpineto P, Toto L, Aloia R, Ciciarelli $\mathrm{V}$, Borrelli E, Vitacolonna E, et al. Neuroretinal alterations in the early stages of diabetic retinopathy in patients with type 2 diabetes mellitus. Eye [Internet]. 2016;30(5):673-9.

17. Shi R, Guo Z, Wang F, Li R, Zhao L, Lin R. Alterations in retinal nerve fiber layer thickness in early stages of diabetic retinopathy and potential risk factors. Curr Eye Res [Internet]. 2018;43(2):244-53.

18. Barber AJ, Lieth E, Khin SA, Antonetti DA, Buchanan AG, Gardner TW.
Neural apoptosis in the retina during experimental and human diabetes: Early onset and effect of insulin. J Clin Invest. 1998;102(4):783-91.

19. Martin PM, Roon P, Van Ells TK, Ganapathy V, Smith SB. Death of retinal neurons in streptozotocininduced diabetic mice. Investig Ophthalmol Vis Sci. 2004;45(9):33306.

20. Ola MS, Nawaz MI, Khan HA, Alhomida AS. Neurodegeneration and neuroprotection in diabetic retinopathy. Int J Mol Sci. 2013;14(2):2559-72.

21. Carl Zeiss Meditec I. Cirrus HD-OCT: How to read the Cirrus reports [Internet]. Review Literature And Arts Of The Americas. California: Carl Zeiss Meditec; 2011. p. 1-13.

22. Fetriyanita S. Hubungan lama menderita diabetes melitus tipe 2 dengan ketebalan lapisan sel ganglion retina dan retinal nerve fiber layer pada pasien tanpa retinopati diabetikum. Univ Andalas. 2018;

23. Hellgren KJ, Agardh E, Bengtsson B. Progression of early retinal dysfunction in diabetes over time: Results of a longterm prospective clinical study. Diabetes. 2014;63(9):3104-11.

24. Adil. Deteksi gangguan fungsi visual pada penderita diabetes melitus tipe II tanpa retinopati diabetik dengan pemeriksaan sensitivitas kontras dan lapangan pandang. Univ Andalas. 2018;

25. Scheen AJ. Pathophysiology of type 2 diabetes. Acta Clin Belg. 2003;58(6):335-41.

26. Adler ML. Type 2 Diabetes Mellitus: Update on Diagnosis, Pathophysiology 
, and Treatment. J Clin Endocrinol Metab. 2010;84(4):1165-71.

27. Canivell S, Gomis R. Diagnosis and classification of autoimmune diabetes mellitus. Autoimmun Rev. 2014;13(45):403-7.

28. Embong Zunaina YN-S. Correlation of Retinal Nerve Fibre Layer Thickness with $\mathrm{HbA1c}$ and Oxidised LDL in Nonproliferative Diabetic Retinopathy. $J$ Diabetes Metab. 2013;04(08):4-9.

29. Ozougwu O. The pathogenesis and pathophysiology of type 1 and type 2 diabetes mellitus. $J$ Physiol Pathophysiol. 2014;4(4):46-57.

30. Chew E, Benson W, Blodi B, Murray T, Olsen T, Regillo $\mathrm{C}$, et al. Diabetic Retinopathy. Am Acad Ophthalmol. 2008;1-39.

31. Simó R, Stitt AW, Gardner TW. Neurodegeneration in diabetic retinopathy: does it really matter? Diabetologia. 2018;61(9):1902-12.

32. Frank N. Etiologic Mechanism in Diabetic Retinopathy. In: Ryan S, editor. Retina. USA: Elsevier; 2006. p. 1253-8.

33. Kim J, Everett. Diabetic Retinopathy. In: Diabetic Retinopathy. CD Regilo. New York: Thieme Medical Publishers; 1999. p. 134-52.

34. Ola MS, Alhomida AS. Neurodegenerative metabolites and neuroprotective strategies in diabetic retinopathy. 2014;661(2).

35. Cumbie BC, Kathie L Hermaye. Current concepts in targeted therapies for the pathophysiology of diabetic microvascular complications. Vasc Health Risk Manag. 2008;55(1):823-
32.

36. Hernández C, Dal Monte M, Simó R, Casini G. Neuroprotection as a Therapeutic Target for Diabetic Retinopathy. $J$ Diabetes Res. 2016;2016(i).

37. Li Q, Puro DG. Diabetes-induced dysfunction of the glutamate transporter in retinal Müller cells. Investig Ophthalmol Vis Sci. 2002;43(9):310916.

38. Abcouwer SF, Gardner TW. Diabetic retinopathy: loss of neuroretinal adaptation to the diabetic metabolic environment. Ann N Y Acad Sci. 2014;1311:174-190.

39. Kern TS, Barber AJ. Retinal ganglion cells in diabetes. $J$ Physiol. 2008;586(18):4401-8.

40. Gastinger MJ, Kunselman AR, Conboy EE, Bronson SK, Barber AJ. Dendrite remodeling and other abnormalities in the retinal ganglion cells of Ins2 Akita diabetic mice. Invest Ophthalmol Vis Sci. 2008 Jun;49(6):2635-42.

41. $\mathrm{Yu} \mathrm{Y}, \mathrm{Chen} \mathrm{H}, \mathrm{Su}$ SB. Neuroinflammatory responses in diabetic retinopathy.

Neuroinflammation [Internet]. 2015;12(1):1-15.

42. Yang JH, Kwak HW, Kim TG, Han J, Moon SW, Yu SY. Retinal neurodegeneration in type II diabetic Otsuka long-evans Tokushima fatty rats. Investig Ophthalmol Vis Sci. 2013;54(6):3844-51.

43. Lopes de Faria JM, Russ H, Costa VP. Retinal nerve fibre layer loss in patients with type 1 diabetes mellitus without retinopathy. $\mathrm{Br} \quad J$ Ophthalmol. 
2002;86(7):725-8.

44. Gábriel R. Neuropeptides and diabetic retinopathy. $\mathrm{Br} J$ Clin Pharmacol. 2013;75(5):1189-201.

45. Barber AJ, Baccouche B. Neurodegeneration in diabetic retinopathy: Potential for novel therapies. Vision Res [Internet]. 2017;139(February 2017):82-92.

46. Stem M, Gardner T. Neurodegeneration in the Pathogenesis of Diabetic Retinopathy: Molecular Mechanisms and Therapeutic Implications. Curr Med Chem. 2013;20(26):3241-50.

47. Vidya D, Shekhar R, Prabodh S, Chowdary NVS, Das MC, Joji Reddy M. Oxidative stress in diabetic retinopathy. $J$ Clin Diagnostic Res. 2011;5(5):994-7.

48. Whitmire W, Al-Gayyar MM, Abdelsaid M, Yousufzai BK, ElRemessy AB. Alteration of growth factors and neuronal death in diabetic retinopathy: what we have learned so far. Mol Vis [Internet]. 2011;17(January):300-8.

49. Sohn EH, van Dijk HW, Jiao C, Kok PHB, Jeong W, Demirkaya N, et al. Retinal neurodegeneration may precede microvascular changes characteristic of diabetic retinopathy in diabetes mellitus. Proc Natl Acad Sci. 2016;113(19):E2655-64.

50. Dong ZM, Wollstein G, Schuman JS. Clinical utility of optical coherence tomography in glaucoma. Investig Ophthalmol Vis Sci. 2016;57(9):55667.

51. Duker J. Handbook of Retinal OCT. London: Elsevier; 2014. 2-27 p.
52. Nordmann J-P. OCT \& Optic Nerve. Paris: Carl Zeiss Meditec; 2017. 42-130 p.

53. Wiley HE, Ferris FL. Nonproliferative Diabetic Retinopathy and Diabetic Macular Edema. In: Ryan SJ, editor. Retina. Los Angeles: Elsevier; 2013. p. 940-64.

54. Gella L, Raman R, Rani P, Sharma T. Spectral domain optical coherence tomography characteristics in diabetic retinopathy. Oman $J$ Ophthalmol. 2014;7(3):126.

55. Mwanza JC, Durbin MK, Budenz DL, Girkin CA, Leung CK, Liebmann JM, et al. Profile and predictors of normal ganglion cell-inner plexiform layer thickness measured with frequencydomain optical coherence tomography. Investig Ophthalmol Vis Sci. 2011;52(11):7872-9.

56. Mwanza J-C, Budenz DL, Godfrey DG, Neelakantan A, Sayyad FE, Chang RT, et al. Diagnostic performance of optical coherence tomography ganglion cell-inner plexiform layer thickness measurements in early glaucoma. Ophthalmology. 2014 Apr;121(4):84954.

57. Ganekal S. Ganglion cell complex scan in the early prediction of glaucoma. Nepal J Ophthalmol a Biannu peerreviewed Acad J Nepal Ophthalmic Soc NEPJOPH. 2012;4(2):236-41.

58. Angraini R. Hubungan Miopia Dengan Ketebalan Retinal Ganglion Cells Pada Mahasiswa Kedokteran. Univ Andalas. 2017; Tesis.

59. Barton J, Benatar M. Functional Visual Anatomy. New Jersey: Humana Press; 
2003. 26-45 p.

60. Wild J. Short wavelength automated perimetry. Acta Ophthalmol Scand. 2001;79:546-59.

61. Heijl A, Patella V, Bengtsson B. STATPAC Analysis Of Single Field. In: The Field Analyzer Primer: Effective Perimetry. California: Carl Zeiss Meditec; 2012. p. 45-59.

62. Gupta A, Choudhry R, Tandon C. Humphrey Field Analyzer. In: Step by Step Visual Field Examination. New Delhi: Jaypee Brothers; 2007. p. 93123.

63. Kahook BYMY, Noecker RJ. How do you interpret a 24-2 Humphrey visual field printout? Glaucoma Today. 2007;(December):57-9.

64. Wild S, Roglic G, Green A, Sicree R, King H. Global Prevalence of Diabetes. Diabetes Care. 2004;27(5):1047-53.

65. Karti O, Nalbantoglu O, Abali S, Ayhan Z, Tunc S, Kusbeci T, et al. Retinal Ganglion Cell Loss in Children With Type 1 Diabetes Mellitus Without Diabetic Retinopathy. Ophthalmic Surgery, Laser and Imaging Retina. 2017;48:473-7.

66. Tabakci B, Demirok G, Topalak Y, Sengun A. The Relationship between Retinal Ganglion Cell Damage with Duration of Diabetes and Diabetes Retinopathy Status. Int J Ophthalmol Clin Res. 2017;4(3):1-7.

67. El-Asrar A, Dralands L, Missoten L, Geboes K. Expression of Antiapoptotic and Proapoptotic Molecules in Diabetic Retinas. Eye. 2007; 21(2):238-45.

68. Susilo T, Rares F, Poluan H. Retinal
Neurodegeneration on the Early Type 2 Diabetes Mellitus. Ophthalmol Ina. 2015;41(1):94-9.

69. Zico OA, El-Shazly AAF, Ahmed EEAH. Short wavelength automated perimetry can detect visual field changes in diabetic patients without retinopathy. Indian Journal of Ophthalmology. 2014;62(4):383-7.

70. Hellgren K-J, Agardh E, Bengtsson B. Progression of Early Retinal Dysfunction in Diabetes Over Time: Results of a Long-term Prospective Clinical Study. Diabetes. 2014;63:3104-11.

71. Henricsson M, Heijl A. Visual fields at different stages of diabetic retinopathy. Acta Ophthalmol Scand. 1994;72:5609.

72. Barber AJ, Lieth E, Khin S, Antonetti D, Buchanan AG, Gardner TW. Neural apoptosis in the retina during experimental and human diabetes. Early onset and effect of insulin1998. 783-91.

73. Barber AJ. A new view of diabetic retinopathy: a neurodegenerative disease of the eye. Progress in NeuroPsychopharmacology \& Biological Psychiatry. 2003;27:283-90. 